\title{
The Bioreduction of Selenite under Anaerobic and Alkaline Conditions Analogous to Those Expected for a Deep Geological Repository System
}

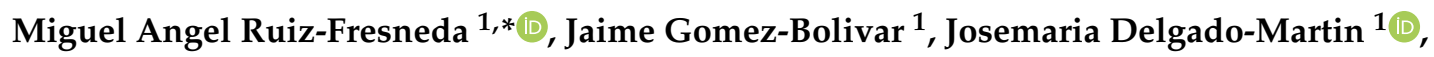 \\ Maria del Mar Abad-Ortega ${ }^{2}$, Isabel Guerra-Tschuschke ${ }^{2}$ and Mohamed Larbi Merroun ${ }^{1}$ (D) \\ 1 Department of Microbiology, University of Granada, 18071 Granada, Spain; jagobo@correo.ugr.es (J.G.-B.); \\ josemariadm93@gmail.com (J.D.-M.); merroun@ugr.es (M.L.M.) \\ 2 Centro de Instrumentación Científica (CIC), University of Granada, 18071 Granada, Spain; \\ mmabad@ugr.es (M.d.M.A.-O.); iguerra@ugr.es (I.G.-T.) \\ * Correspondence: mafres@correo.ugr.es
}

Academic Editors: Encarnación Ruiz Ramos and Francisco Espínola

Received: 15 September 2019; Accepted: 22 October 2019; Published: 27 October 2019

\begin{abstract}
The environmental conditions for the planned geological disposal of radioactive waste -including hyper-alkaline $\mathrm{pH}$, radiation or anoxia-are expected to be extremely harsh for microbial activity. However, it is thought that microbial communities will develop in these repositories, and this would have implications for geodisposal integrity and the control of radionuclide migration through the surrounding environment. Nuclear waste contains radioactive isotopes of selenium (Se) such as ${ }^{79} \mathrm{Se}$, which has been identified as one of the main radionuclides in a geodisposal system. Here, we use the bacterial species Stenotrophomonas bentonitica, isolated from bentonites serving as an artificial barrier reference material in repositories, to study the reduction of selenite $\left(\mathrm{Se}^{\mathrm{IV}}\right)$ under simulated geodisposal conditions. This bacterium is able to reduce toxic $\mathrm{Se}^{\mathrm{IV}}$ anaerobically from a neutral to alkaline initial $\mathrm{pH}$ (up to $\mathrm{pH} 10$ ), thereby producing elemental selenium $\left(\mathrm{Se}^{0}\right)$ nanospheres and nanowires. A transformation process from amorphous Se (a-Se) nanospheres to trigonal Se (t-Se) nanowires, through the formation of monoclinic Se (m-Se) aggregates as an intermediate step, is proposed. The lesser solubility of $\mathrm{Se}^{0}$ and $\mathrm{t}$-Se makes $\mathrm{S}$. bentonitica a potential candidate to positively influence the security of a geodisposal system, most probably with lower efficiency rates than those obtained aerobically.
\end{abstract}

Keywords: Stenotrophomonas bentonitica; selenite; reduction; alkaline; anaerobic; disposal

\section{Introduction}

Today, there is a growing concern about the extensive use of nuclear technology due to an increasing radioactive waste inventory. The total amount of nuclear waste-extremely hazardous to the environment and living organisms-may increase in the near future with the potential development of the next generation of nuclear reactors. For this reason, the deep geological repository (DGR) of intermediate and high-level waste (ILW and HLW) has been adopted by many countries for safe storage and isolation [1]. Radioactive residues will accordingly be deposited in steel, iron, or concrete containers and then backfilled with bitumen, a cement matrix, or bentonite clays at a depth of 500-1000 m, in different host rocks depending on the country. Clay formations are to play a crucial role in many DGR designs as host rock or engineered-barriers in France, Belgium, and Switzerland [2]. Specifically, bentonite clays will be employed for the mechanical, hydraulic, and thermal protection of the containers owing to their physical and geochemical properties [3]. It is believed that aerobic conditions will prevail in a DGR system after closure, since oxygen is sure to enter during construction and operational 
periods. In the post-closure period, anaerobic conditions are likely to be established, with a wide range of electron acceptors, organic matter, and other compounds available. In addition, hyperalkaline $(\sim \mathrm{pH} 12)$ conditions will dominate due to the extensive use of cementitious materials [4].

The environment within a DGR system is estimated to be extremely harsh for living organisms. The presence of radionuclides, high-radiation levels, and limited space for microbial colonization, in addition to the above mentioned anaerobic and hyperalkaline conditions, would restrict microbial viability and activity. However, the capacity of many microorganisms to colonize similarly extreme environments, e.g., hyper-alkaline spring waters or hydrothermal vents, is well known $[5,6]$. Indeed, it is assumed that different geochemical processes, such as the degradation of cellulose from packaging materials, disposable clothing, and surface wipes present in ILW, can lead to the generation of nutrients and growth substrates that might support the growth of microorganisms. The restoration of water after a thousand years could result in the release of diverse chemical compounds from bitumen and concrete materials used in some DGR systems, including organic matter, electron donors and acceptors $\left(\mathrm{NO}_{3}{ }^{-}\right)$, gases $\left(\mathrm{H}_{2}\right)$, etc. The utilization of electron donors and acceptors by anaerobic microorganisms could lead to enzymatic reduction and, therefore, the immobilization of radionuclides like $\mathrm{U}^{\mathrm{VI}}, \mathrm{Tc}^{\mathrm{VII}}, \mathrm{Np}^{\mathrm{V}}$, or $\mathrm{Se}^{\mathrm{IV}}$ within the geodisposal system [7,8]. It has been reported that selenium (Se) is present in the tetravalent oxidation state (+IV) in high-level radioactive waste [9]. Water-soluble and toxic Se compounds commonly exist in the oxidation states $+\mathrm{IV}$ and $+\mathrm{VI}$ as selenite $\left(\mathrm{SeO}_{3}{ }^{2-}\right)$ and selenate $\left(\mathrm{SeO}_{4}{ }^{2-}\right)$, respectively, while insoluble and harmless Se compounds occurs in oxidation state 0 as elemental Se [10]. The microbial reduction of $\mathrm{Se}^{\mathrm{IV}}$ has been reported under both aerobic and anaerobic conditions in a wide range of microorganisms. For example, some bacterial strains, such as Stenotrophomonas maltophilia SeITE02, Comamonas testosteroni S44, and Bacillus cereus, can aerobically reduce $\mathrm{Se}^{\mathrm{IV}}$ to $\mathrm{Se}^{0}$ [11-13]. Se $\mathrm{IV}^{\mathrm{IV}}$ can also be biotransformed anaerobically to $\mathrm{Se}^{0}$ by certain bacteria, such as Azoarcus sp. CIB, S. maltophilia, and Shewanella oneidensis MR-1 [14-16]. Thus, it is important to study the impact of microbial processes in the transport and mobility of Se through the geodisposal system under conditions relevant to a DGR (aerobic, anaerobic, alkaline conditions, etc.).

The aim of the present work is to investigate the reduction of $\mathrm{Se}^{\mathrm{IV}}$ by the bentonite-isolated bacterium S. bentonitica under anaerobic and alkaline conditions, comparable to those likely to occur in future nuclear waste repositories. In a previous study, we described this interaction under aerobic conditions considering its relevance to nuclear repositories [17]. Specifically, we demonstrated the aerobic bioreduction of $\mathrm{Se}^{\mathrm{IV}}$ to different amorphous and crystalline $\mathrm{Se}^{0}$ nanostructures. Amorphous Se (a-Se) nanostructures are apparently transformed to Se crystals through the role of organic matter. The previous results suggested that $S$. bentonitica would decrease the solubility, and hence the mobility, of Se in the environment surrounding DGRs. Only few papers, however, describe the impact of microbial processes on radionuclide mobility under alkaline conditions analogous to the DGR system [18,19].

To the best of our knowledge, ours is the first study describing the bioreduction of $\mathrm{Se}^{\mathrm{IV}}$ to $\mathrm{Se}^{0}$ anaerobically under different initial $\mathrm{pH}$ conditions (from $\mathrm{pH} 7$ to 10) by means of a bacterial strain isolated from Spanish bentonites (Almería, Spain) and selected for DGRs because of their advantageous properties [20]. Flow cytometry studies clearly show that anoxia and $\mathrm{Se}^{\mathrm{IV}}$ stress negatively affect bacterial viability and activity; although minor viability and activity levels were detected, no cell proliferation was found under the prevailing conditions. In-depth analysis by electron microscopy showed the production of individual and aggregated Se nanospheres and nanowires as reduction products after the Se-bacteria interaction under anaerobic and alkaline conditions (initial pH 10). The selected-area electron diffraction (SAED) pattern of individual Se nanospheres indicated their amorphous nature. However, Raman spectroscopy equipped to a variable pressure field emission scanning electron microscopy (VP-FESEM) indicated the crystalline structure of the Se aggregates (monoclinic Se) and nanowires (trigonal Se), suggesting a transformation process from amorphous to crystalline Se. Not only the oxidation state but also the shape and the structure of the Se reduction products can influence their solubility and mobility. The present study further demonstrates the influence that $S$. bentonitica could have on future DGR systems by reducing the toxicity and mobility 
of $\mathrm{Se}^{\mathrm{IV}}$ under an anoxic and high-pH environment, analogous to those that would develop in the repositories of radioactive waste.

\section{Results and Discussion}

\section{1. $S e^{I V}$ Reduction under Anaerobic and Neutral $p H$ Conditions}

\subsection{1. $\mathrm{Se}^{\mathrm{IV}}$ Reduction and Growth Profile}

The growth and $\mathrm{Se}^{\mathrm{IV}}$ reduction of $\mathrm{S}$. bentonitica under anoxic conditions was evaluated in the presence of a wide range of added electron donors (sodium acetate, citrate, pyruvate, etc.) and acceptors (sodium nitrate, iron(III) hydroxide, ferric citrate, etc.) at neutral $\mathrm{pH}$ conditions in an R2A* medium (a modified composition). The literature data show a great number of compounds that can be used by many microorganisms as electron donors or acceptors in reducing $\mathrm{Se}^{\mathrm{VI}}$ and $\mathrm{Se}^{\mathrm{IV}}$. A high reduction rate of $\mathrm{Se}^{\mathrm{IV}}$ was achieved by Veillonella atypica when hydrogen $\left(\mathrm{H}_{2}\right)$ was used as the electron donor under anaerobic conditions, but no reduction was seen when the cells were supplemented with acetate or formate as an electron source [21]. Meanwhile, Kessi and Hanselmann [22] hypothesized that reduced glutathione (GSH) functions as the main electron donor reacting with $\mathrm{Se}^{\mathrm{IV}}$ in Rhodospirillum rubrum and Escherichia coli. The possible role of GSH and other reactive thiol compounds in $\mathrm{Se}^{\mathrm{IV}}$ reduction was likewise suggested within the genus Stenotrophomonas by S. maltophilia SeITE02 [10]. Other electron sources, such as acetate, lactate, formate, and pyruvate, have been put forth as electron donors in the $\mathrm{Se}^{\mathrm{IV}}$ reductions in Geobacter sulfurreducens, Shewanella sp. HN-41, and S. oneidensis MR-1 [16,23-25]. $\mathrm{Se}^{\mathrm{IV}}$ acts as the terminal electron acceptor for many microorganisms [26]. However, the use of iron $\left(\mathrm{Fe}{ }^{\mathrm{III}}\right)$, nitrate $\left(\mathrm{NO}_{3}{ }^{-}\right)$, nitrite $\left(\mathrm{NO}_{2}{ }^{-}\right)$, or sulphite $\left(\mathrm{SO}_{3}{ }^{2-}\right)$ as electron acceptors by respiratory reductases might support the reduction of $\mathrm{Se}^{\mathrm{IV}}$ in some microorganisms $[27,28]$. In the present study, the highest $\mathrm{Se}^{\mathrm{IV}}$ reduction efficiency-quantified as red precipitate production-by the cells of S. bentonitica was observed when sodium acetate and nitrate were added.

Both acetates and nitrates are compounds that will be present in the geodisposal system of radioactive waste. Among other sources, acetate can derive from the oxidation of glucose and degradation of the phthalic acid esters (PVC plasticisers) characteristic of ILW, while nitrates are mainly contained within bitumen waste or as a product of the nitrogen biogeochemical cycle [23-31]. The presence of acetate and nitrates within the repositories could thus support the reduction of $\mathrm{Se}^{\mathrm{IV}}$ by the cells of S. bentonitica when anaerobic conditions prevail. For this reason, they were selected for the rest of the experiments as electron donor and acceptor sources, respectively. In addition, $\mathrm{Se}^{\mathrm{IV}}$ reduction was observed when anaerobically incubating the S. bentonitica in the PIPES buffer without the addition of an electron donor or acceptor, suggesting that $\mathrm{Se}^{\mathrm{IV}}$ could act as the terminal electron acceptor.

In the absence of $\mathrm{Se}^{\mathrm{IV}}$, only when the cultures were amended with sodium acetate and sodium nitrate was a limited increase in the total cell protein observed during the first $12 \mathrm{~h}$ of incubation (Figure 1). Notwithstanding, no growth was detected in the presence of $\mathrm{Se}^{\mathrm{IV}}$ at any concentration tested $(0.5$ and $1 \mathrm{mM}$ ) (Figure 1), despite the fact that previous studies revealed the capacity of this bacterium to grow aerobically under $\mathrm{Se}^{\mathrm{IV}}$ stress [17]. Such results point to a toxic effect of $\mathrm{Se}^{\mathrm{IV}}$ on $S$. bentonitica cells under anaerobic conditions. Nevertheless, the red precipitates produced in all the cultures amended with $\mathrm{Se}^{\mathrm{IV}}$ clearly indicate the ability of this bacterium to anaerobically reduce $\mathrm{Se}^{\mathrm{IV}}$ to $\mathrm{Se}^{0}$. The non-production of Se red precipitates in $\mathrm{Se}^{\mathrm{IV}}$-untreated cultures and $\mathrm{Se}^{\mathrm{IV}}$-treated media (abiotic controls) confirmed $\mathrm{Se}^{\mathrm{IV}}$ reduction as a biological process. 


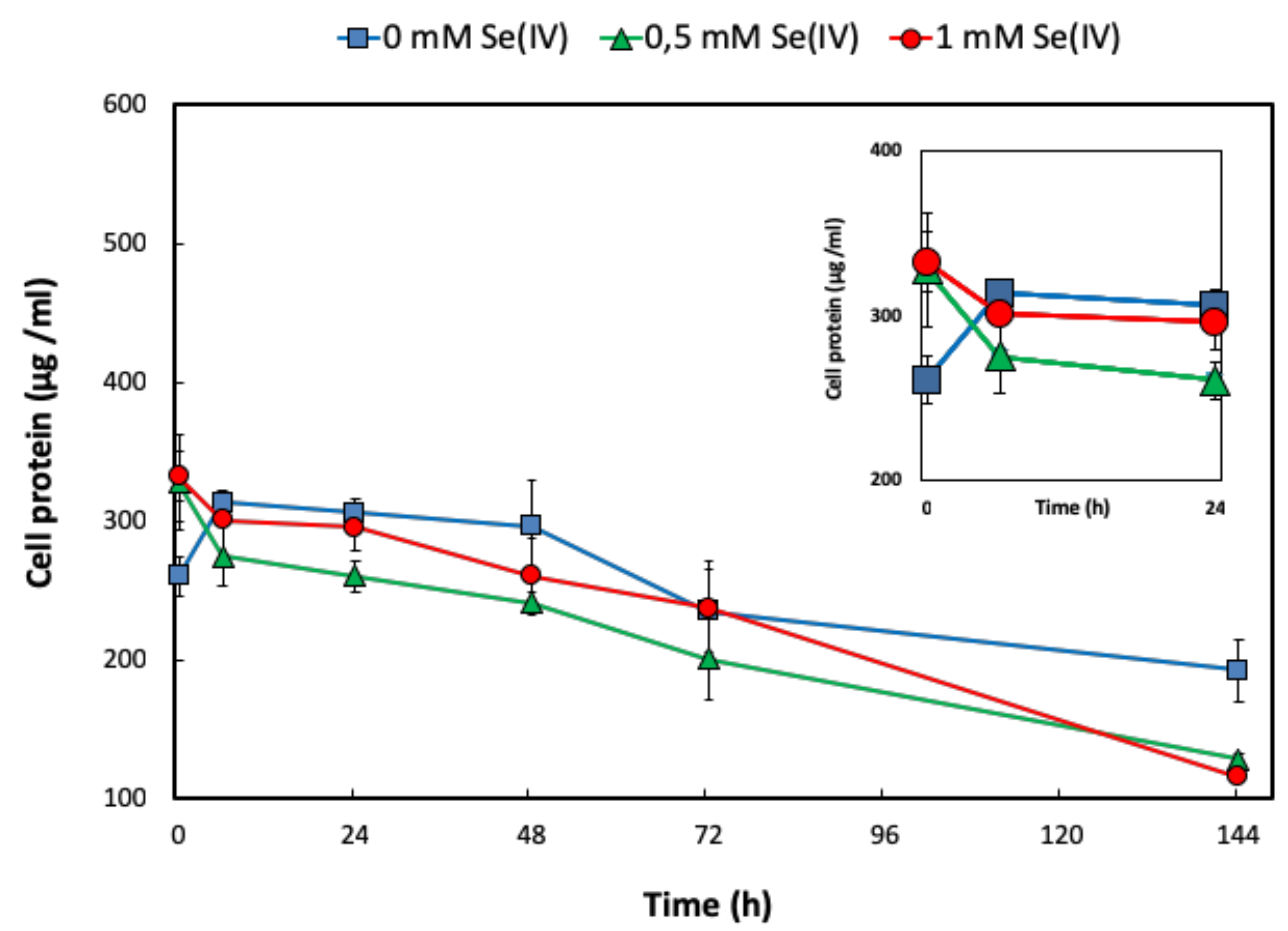

Figure 1. Anaerobic growth curves of $S$. bentonitica in an $\mathrm{R}^{2} \mathrm{~A}^{*}$ medium with sodium acetate and sodium nitrate in the presence of different $\mathrm{Se}^{\mathrm{IV}}$ concentrations (0 to $\left.1 \mathrm{mM}\right)$. The inset graph shows a magnification of the growth curve in the first $24 \mathrm{~h}$. Data are presented as the averages \pm standard errors.

\subsubsection{Cell Viability and Metabolic Activity}

The effect of $\mathrm{Se}^{\mathrm{IV}}$ on the cell viability of S. bentonitica was studied by means of the live-dead staining approach, conducted with propidium iodide (PI) and fluorescein diacetate (FDA). PI enters into cells with damaged membranes, staining the nucleic acids of dead cells [32], whereas FDA stains viable cells [33]. To test metabolic activity, the fluorescent dye $\mathrm{DiOC}_{6}$ was used in order to bind the polarized membranes of the active cells [34].

The percentages of viable and active cells of $S$. bentonitica, both untreated and treated with $2 \mathrm{mM}$ $\mathrm{Se}^{\mathrm{IV}}$ incubated anaerobically at a neutral $\mathrm{pH}$ from $12 \mathrm{~h}$ to $144 \mathrm{~h}$, are displayed in Figure 2. Cell viability was negatively affected by $\mathrm{Se}^{\mathrm{IV}}$. Specifically, $32.7 \%, 41.5 \%$, and $1.7 \%$ of cell populations were found to be viable after 12,60 , and $144 \mathrm{~h}$ of incubation, respectively, in the presence of $2 \mathrm{mM} \mathrm{Se}^{\mathrm{IV}}$. In contrast, higher viable cell populations $(100 \%, 100 \%$, and $17.3 \%)$ were observed in untreated samples at the same incubation times. Our previous studies under aerobic conditions gave higher viability values for the cells after $144 \mathrm{~h}$ of incubation in the presence of $2 \mathrm{mM} \mathrm{Se} \mathrm{IV}^{\mathrm{IV}}$ (unpublished data). These results underline the influence of anoxia and $\mathrm{Se}^{\mathrm{IV}}$ on the viability of S. bentonitica cells. On the other hand, the metabolic activity test generally showed a lower oxidative response under $2 \mathrm{mM} \mathrm{Se}^{\mathrm{IV}}$ stress (compared with $\mathrm{Se}^{\mathrm{IV}}$-untreated cells) at all times assayed, except at $144 \mathrm{~h}$. Specifically, 33.4\%, 45\%, and 50\% were found to be active after 12,60 , and $144 \mathrm{~h}$ at $2 \mathrm{mM} \mathrm{Se}^{\mathrm{IV}}$ stress, while $85.6 \%, 93.3 \%$, and $12.4 \%$ of the cells were active in untreated samples. The increases in cell activity after $144 \mathrm{~h}$ in the presence of $\mathrm{Se}^{\mathrm{IV}}$ compared to the $\mathrm{Se}^{\mathrm{IV}}$-untreated cells might be explained by the cellular metabolic response to $\mathrm{Se}^{\mathrm{IV}}$ stress. Our previous studies under aerobic conditions showed similar behavior (unpublished data). 

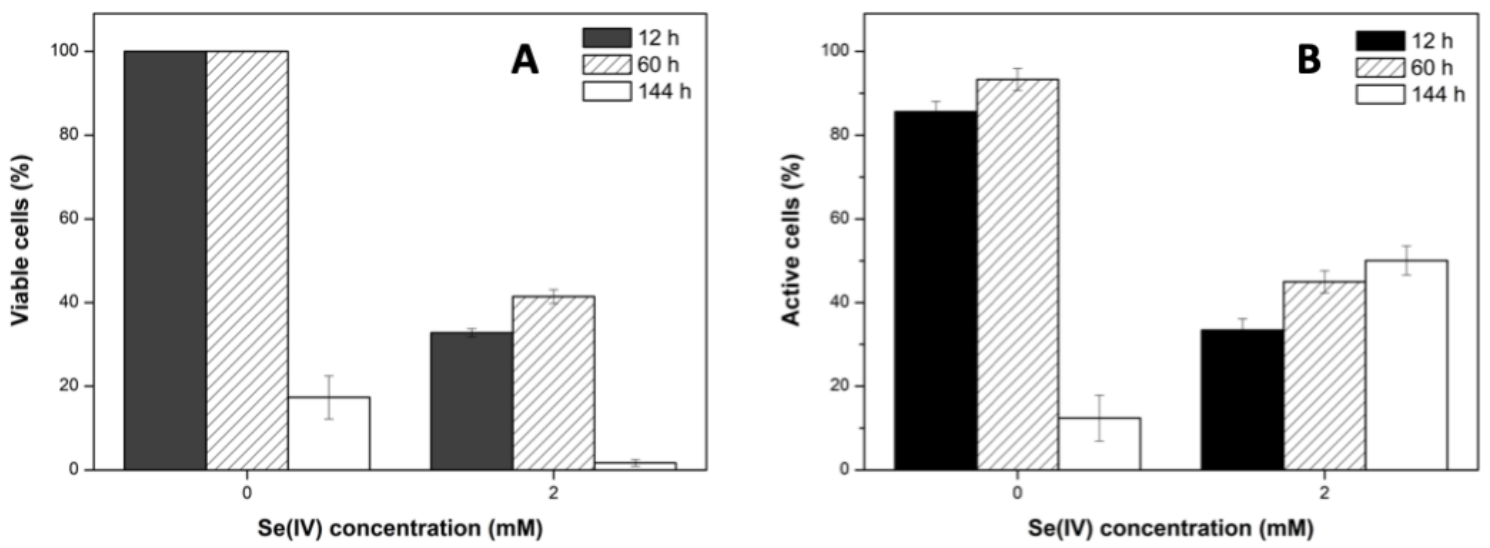

Figure 2. Percentage of viable (A) and active cells (B) of S. bentonitica under different $\mathrm{Se}^{\mathrm{IV}}$ concentrations $(0$ and $2 \mathrm{mM})$ and contact times $(12,60$, and $144 \mathrm{~h})$ under anaerobic and neutral $\mathrm{pH}$ conditions.

\section{2. $S e^{I V}$ Reduction under Anaerobic and Alkaline Conditions}

Se's reduction ability was also studied under anaerobic and alkaline initial $\mathrm{pH}$ conditions analogous to those expected in a DGR environment. The colour of the $\mathrm{Se}^{\mathrm{IV}}$-treated cultures $(2 \mathrm{mM})$ of S. bentonitica turned reddish at initial $\mathrm{pH} 8,9$, and 10 after 24/48 h of incubation (Figure 3). However, no red precipitates were observed at $\mathrm{pH} 11$, probably due to the non-proliferation of the cells under these conditions. The latter hypothesis is supported by previous investigations indicating that S. bentonitica grows at $\mathrm{pH}$ 5-10 under aerobic conditions [35]. As described for the anaerobic experiments in Section 2.1., no colour change in the $\mathrm{Se}^{\mathrm{IV}}$-untreated cultures and $\mathrm{Se}^{\mathrm{IV}}$-treated media confirmed the bioreduction of $\mathrm{Se}^{\mathrm{IV}}$. Many bacterial strains are known to reduce $\mathrm{Se}^{\mathrm{IV}}$ anaerobically $[14,16]$. However, to the best of our knowledge, this is the first study describing the microbial reduction of $\mathrm{Se}^{\mathrm{IV}}$ at an alkaline $\mathrm{pH}$ (up to $\mathrm{pH} 10$ ) under anaerobic conditions. These results reveal the ability of the bentonite isolate $S$. bentonitica to reduce Se toxic forms to non-toxic Se under the analogous conditions expected in a DGR system. Therefore, we propose that this species of the genus Stenotrophomonas could contribute to the immobilization of Se within the DGR concept.

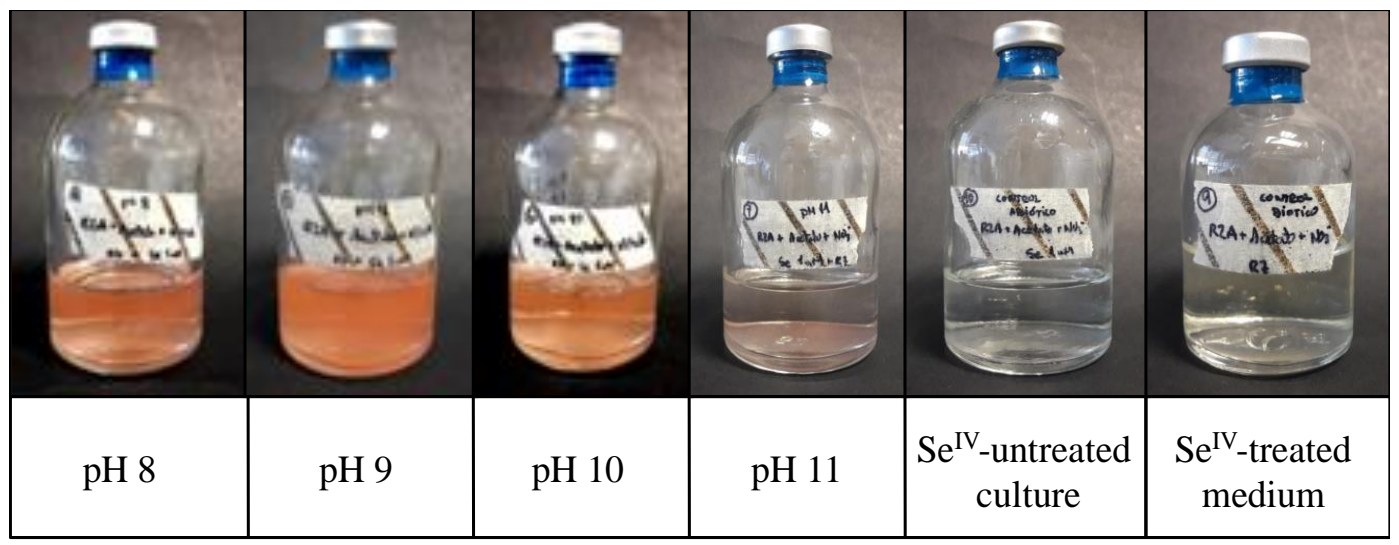

Figure 3. Cultures of $S$. bentonitica adjusted to $\mathrm{pH} 8,9,10$, and 11 showing the reduction of $2 \mathrm{mM} \mathrm{Se}^{\mathrm{IV}}$ from $\mathrm{pH} 8$ to 10 , as indicated by their reddish colour. $\mathrm{Se}^{\mathrm{IV}}$-untreated cultures and the $\mathrm{Se}^{\mathrm{IV}}$-treated medium were employed as controls.

To study the effect of Se and the cells on the $\mathrm{pH}$ variation of the samples (adjusted to $\mathrm{pH} 10$ ), the $\mathrm{pH}$ was measured at different times during incubation. Abiotic controls ( $\left(\mathrm{Se}^{\mathrm{IV}}\right.$-treated media) showed no variation of the $\mathrm{pH}$ over time, remaining around 10 during the entire assay (Figure 4). In the presence of bacteria, however, both untreated and treated cultures of $S$. bentonitica showed a 
decrease, respectively, from $\mathrm{pH} 10$ to $\mathrm{pH} 7$ and 8, by increasing incubation time (Figure 4). The cells are responsible for this decrease in $\mathrm{pH}$, perhaps as a consequence of the bacterial metabolic activity responding to these stressful conditions, as suggested by the flow cytometry results.

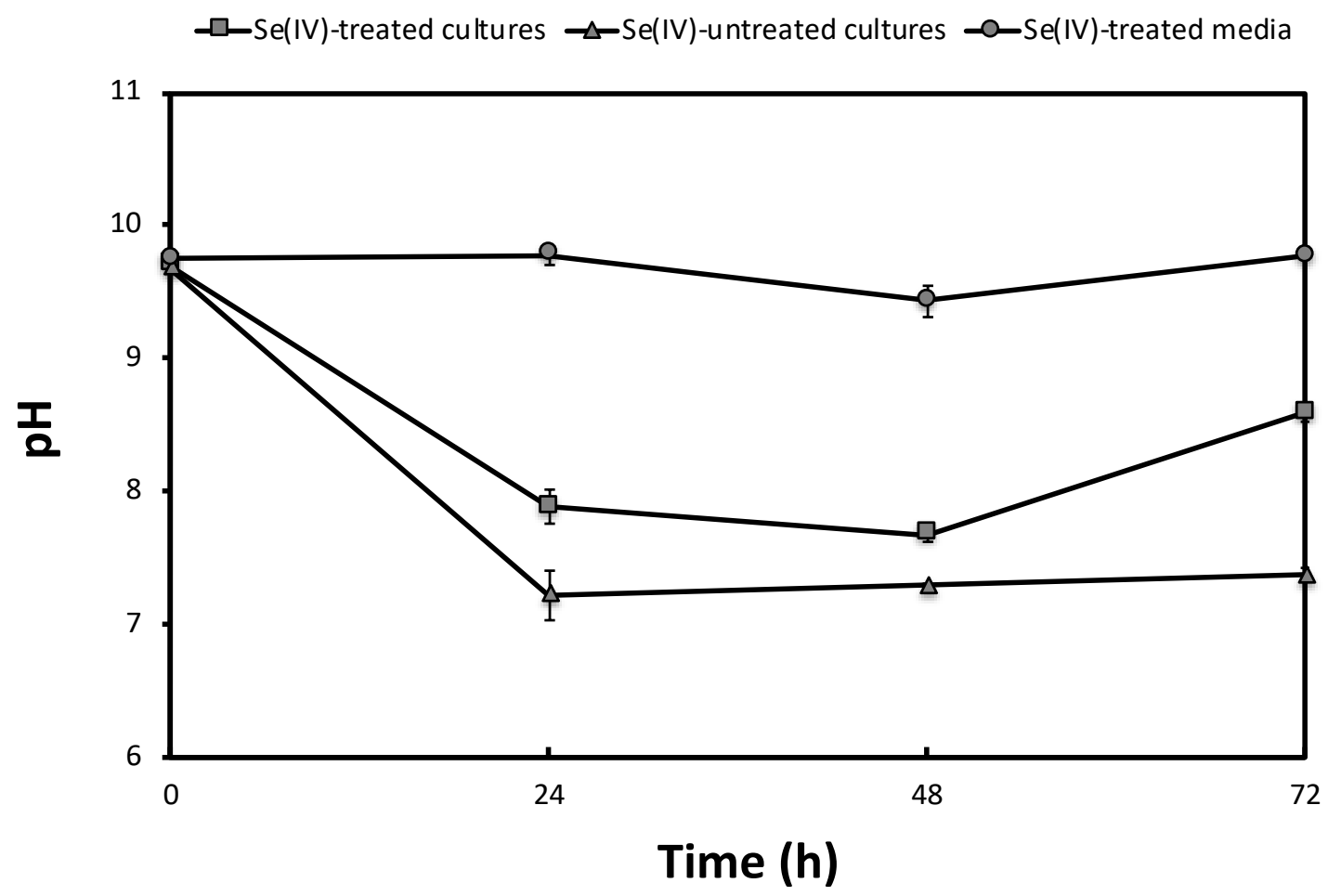

Figure 4. Time course of $\mathrm{pH}$ variation in $\mathrm{Se}^{\mathrm{IV}}$-treated $(2 \mathrm{mM})$ and untreated cultures of S. bentonitica adjusted to $\mathrm{pH} 10$ under anaerobic conditions. $\mathrm{Se}^{\mathrm{IV}}$-treated media were employed as abiotic controls. $\mathrm{Se}^{\mathrm{IV}}$ and cells were added at zero time. Each curve shows the means based on the results of triplicates.

Rizoulis et al. [36] studied the reduction of different electron acceptors of relevance to ILW in natural alkaline sediments set at $\mathrm{pH} 10,11$, and 12. Similar to our experiments, they noted a slight drop in $\mathrm{pH}$ during incubation, probably due to the formation of $\mathrm{CO}_{2}$ from the metabolism of lactate, acetate, and other carbon sources present in the sediments. In our case, $S$. bentonitica was able to oxidize acetate to $\mathrm{CO}_{2}$, which in turn led to a decreased in the $\mathrm{pH}$ of the medium (to 7-8) where $\mathrm{Se}^{\mathrm{IV}}$ reduction occurs.

\subsection{Electron Microscopic Characterization of $S e^{I V}$ Bioreduction Products}

Ultrathin sections showed electron-dense nanospheres produced by the cells of $S$. bentonitica on the surface and within the intracellular and extracellular space after $144 \mathrm{~h}$ incubation on $\mathrm{Se}^{\mathrm{IV}}$ at a neutral $\mathrm{pH}$ (Figure 5A,B). The size of both intracellular and extracellular nanospheres ranged between 100 and $200 \mathrm{~nm}$ (Figure 5A,B). EDX microanalysis confirmed their Se composition (Figure 5C). In addition, the SAED pattern derived from a single nanosphere showed an amorphous nature (Figure 5D). 

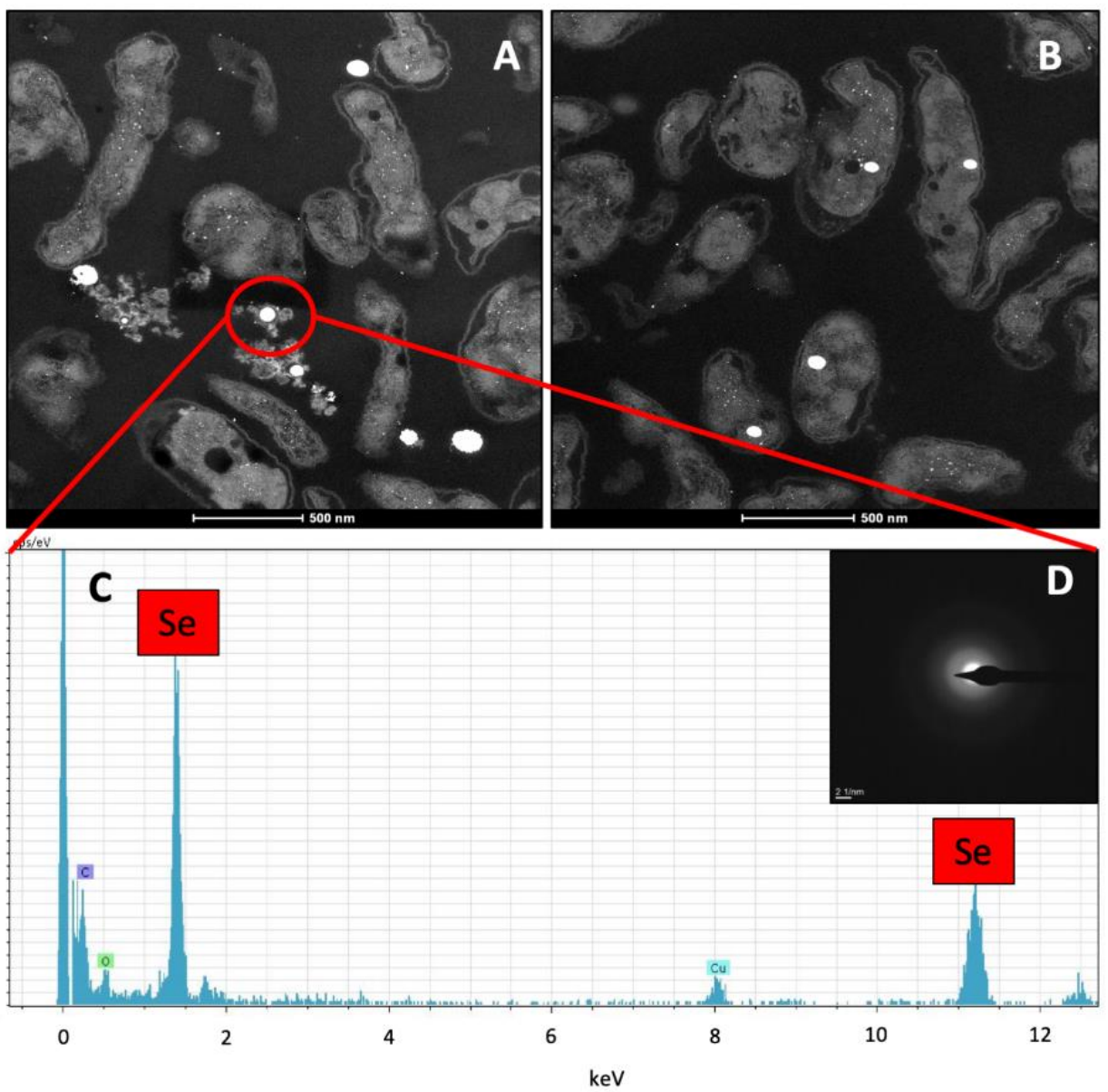

Figure 5. HAADF-STEM analysis of an ultrathin-sectioned S. bentonitica sample incubated anaerobically at a neutral $\mathrm{pH}$ in the presence of $\left.2 \mathrm{mM} \mathrm{Se} \mathrm{IV}^{\mathrm{IV}} \mathbf{A}, \mathbf{B}\right)$. EDX analysis revealed the Se composition of the electron-dense nanospheres (C) located both intracellular and extracellularly (A,B). SAED pattern derived from an individual Se granule (D). Scale bars: $500 \mathrm{~nm}(\mathbf{A}, \mathbf{B})$.

Likewise, we noted the presence of individual Se nanospheres located extracellularly, intracellularly, and attached on the cell surface after $144 \mathrm{~h}$ of anaerobic incubation at an initial $\mathrm{pH}$ of 10 by using a VP-FESEM system (Figure 6A-D). In addition to Se, EDX microanalysis revealed the presence of $\mathrm{S}$ (Figure 6B), suggesting the relevant contribution of thiol-containing biomolecules, such as GSH in the reduction pathway of $\mathrm{Se}^{\mathrm{IV}}$. The Se nanospheres formed aggregates (Figure 6C,D), as observed in aerobic cultures of $S$. bentonitica treated with $\mathrm{Se}^{\mathrm{IV}}$ [17]. The formation of Se aggregates by S. bentonitica could lead to the transformation of amorphous Se (a-Se) nanospheres to trigonal Se (t-Se) nanostructures with high stability, as reported by Ruiz-Fresneda et al. [17], when this bacterium was grown aerobically. The transformation from a-Se to t-Se is a time-dependent process. The a-Se nanospheres are initially released to the extracellular matrix from the cytoplasm $(24 \mathrm{~h})$ and most probably start to form aggregates on the axis of flagella-like proteins after 48-72 h. The aggregation of Se nanoparticles (SeNPs) using proteins as a template may play a crucial role in the transformation and crystallization mechanism $[17,37]$. Finally, after $144 \mathrm{~h}$, the aggregates crystallize, producing $\mathrm{t}$-Se nanostructures of different shapes (nanowires, hexagons, and polygons) and sizes. However, further investigations are needed to confirm that a transformation process occurs under conditions such as those employed in the present study. 


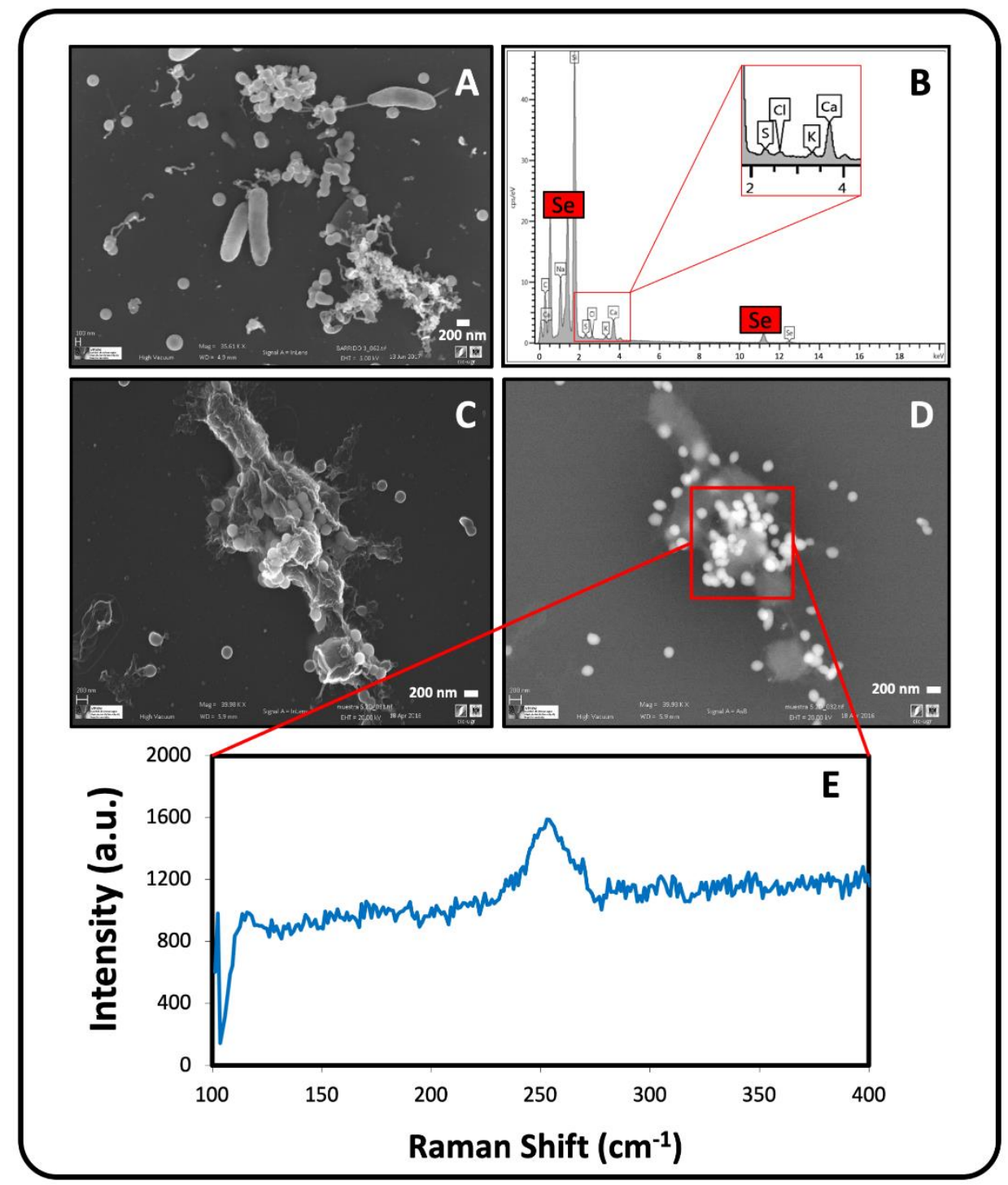

Figure 6. VP-FESEM micrographs of Se nanospheres located extracellularly, intracellularly and attached on lysed cells of $S$. bentonitica (A,C,D) produced anaerobically at an initial $\mathrm{pH}$ of 10 . EDX analysis showing the Se and $\mathrm{S}$ composition of the nanospheres (B). Raman analysis derived from Se nanosphere accumulations (E). Scale bars: $200 \mathrm{~nm}(\mathbf{A}, \mathbf{C}, \mathbf{D})$.

The Raman scattering spectrum derived from the observed Se nanosphere accumulations exhibited an intense peak at $254 \mathrm{~cm}^{-1}$ (Figure 6E). Kora and Rastogi [38] suggested that a resonance peak at $254 \mathrm{~cm}^{-1}$ could be attributed to a-Se as a result of Se atoms being irregularly arrayed in disordered chains. These findings contrast with those previously obtained for the SeNPs synthesized by S. bentonitica under aerobic conditions, where a peak at $235 \mathrm{~cm}^{-1}$ corresponding to t-Se was observed. Other authors indicated that a peak centered at $254 \mathrm{~cm}^{-1}$ is characteristic of crystalline monoclinic Se (m-Se) [39,40]. Over the last century, many contradictory studies of the a-Se structure have come to light [41]. The three allotropes of $\mathrm{m}$-Se are a deep red colour and have $\mathrm{Se}_{8}$ rings as structural units within their unit cell [42]. Amorphous Se (red or black) is thought to contain 2 polymeric chains $\left(\mathrm{Se}_{\mathrm{n}}\right)$ and $\mathrm{Se}_{8}$ monomeric rings $[43,44]$. It is, therefore, very complicated to distinguish between a-Se and $\mathrm{m}-\mathrm{Se}$ structures. The Se aggregates produced by S. bentonitica cells could be amorphous or monoclinic, in contrast to the individually distributed Se nanospheres described above as amorphous by means of SAED. However, it is well known that a-Se could be transformed to m-Se nanostructures, which in turn could be transformed to $t-S e$ as one of the most thermodynamically stable phases $[37,45]$. Accordingly, 
the formation of m-Se aggregates by S. bentonitica may be an intermediate thermodynamic step during the possible transformation to t-Se. A great abundance of organic matter and organic filaments probably corresponding to flagella-like proteins were detected surrounding SeNPs and bacterial cells (Figure 7A-B). The VP-FESEM images clearly show that the SeNPs embedded in this organic matrix are mainly composed by proteins, suggesting their role in aggregation and transformation.
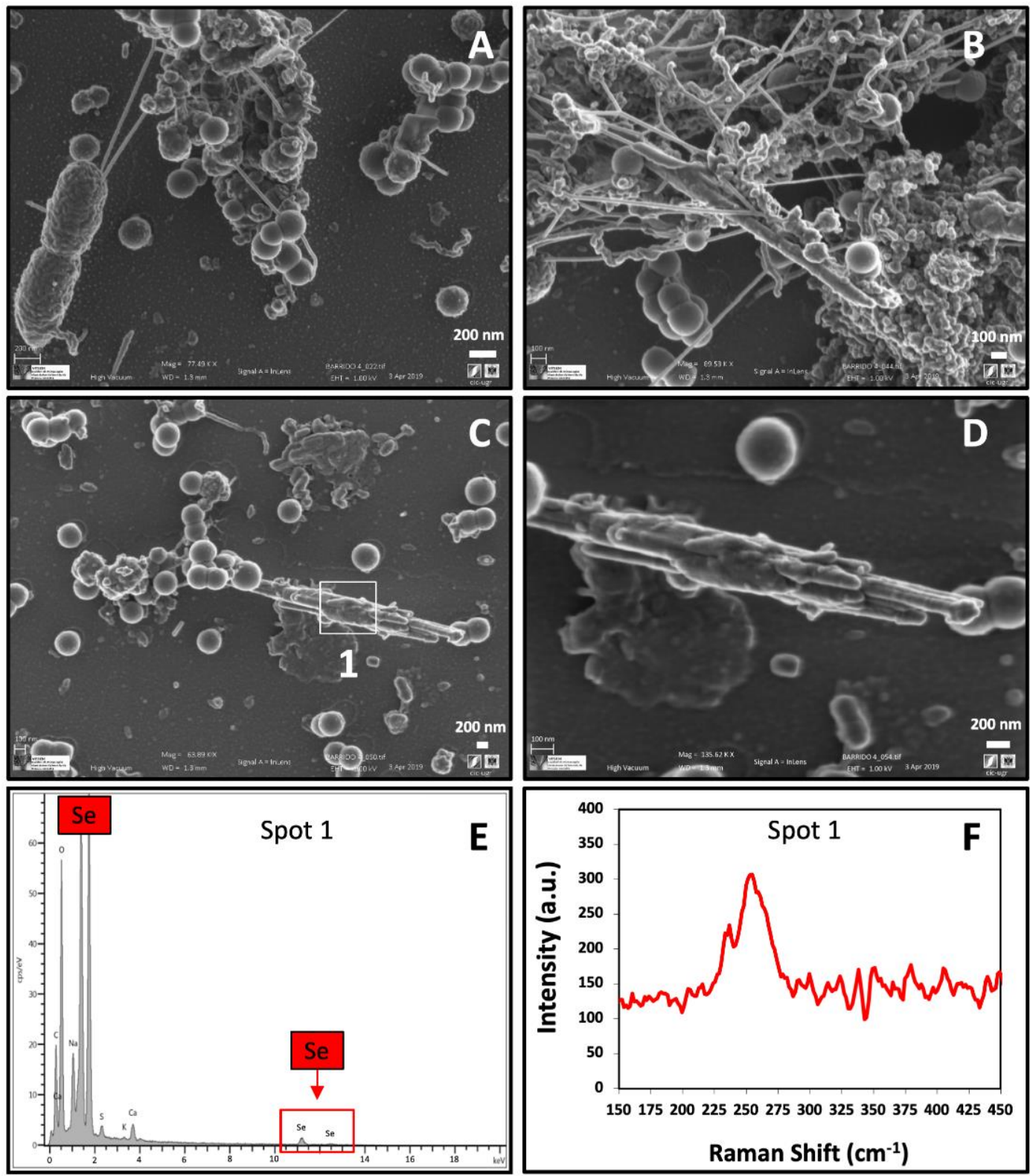

Figure 7. VP-FESEM micrographs showing SeNPs associated with organic materials and filaments $(\mathbf{A}, \mathbf{B})$ and Se nanowires within the extracellular space $(\mathbf{C}, \mathbf{D})$ under anaerobic conditions at an initial $\mathrm{pH}$ of 10. EDX analysis of an individual nanowire indicates its Se composition (E). Raman scattering spectrum derived from the same nanowire (F). Scale bars: $200 \mathrm{~nm}(\mathbf{A}, \mathbf{C}, \mathbf{D})$ and $100 \mathrm{~nm}(\mathbf{B})$.

Finally, few extracellular Se nanowires could be detected in the proximity of Se aggregates (Figure 7B-D). The Raman scattering spectrum derived from the nanowires displayed two main peaks, one at $236 \mathrm{~cm}^{-1}$ and $254 \mathrm{~cm}^{-1}$ (Figure $7 \mathrm{~F}$ ). The resonance peak at $236 \mathrm{~cm}^{-1}$ could be linked to t-Se, while $254 \mathrm{~cm}^{-1}$ could be attributed, as mentioned before, to the intermediate thermodynamic phase, a-Se or $\mathrm{m}$-Se. This suggests that a transformation process could take place, likely along the lines 
reported by Ruiz-Fresneda et al. [17], including several steps. The intracellular Se nanospheres would be released through the bacterial cell lysis, as indicated by the seriously damaged cells observed (Figure 8). Afterwards, they formed aggregates within the extracellular matrix, probably using cellular organic matter and flagella-like proteins as a template (Figure 8). Finally, the Se nanowires appear to originate from the accumulation and aggregation of the nanospheres attached to these organic matter and protein filaments (Figure 8). In the proposed mechanism, the individual a-Se nanospheres would crystallize to m-Se aggregates and $\mathrm{t}$-Se nanowires.
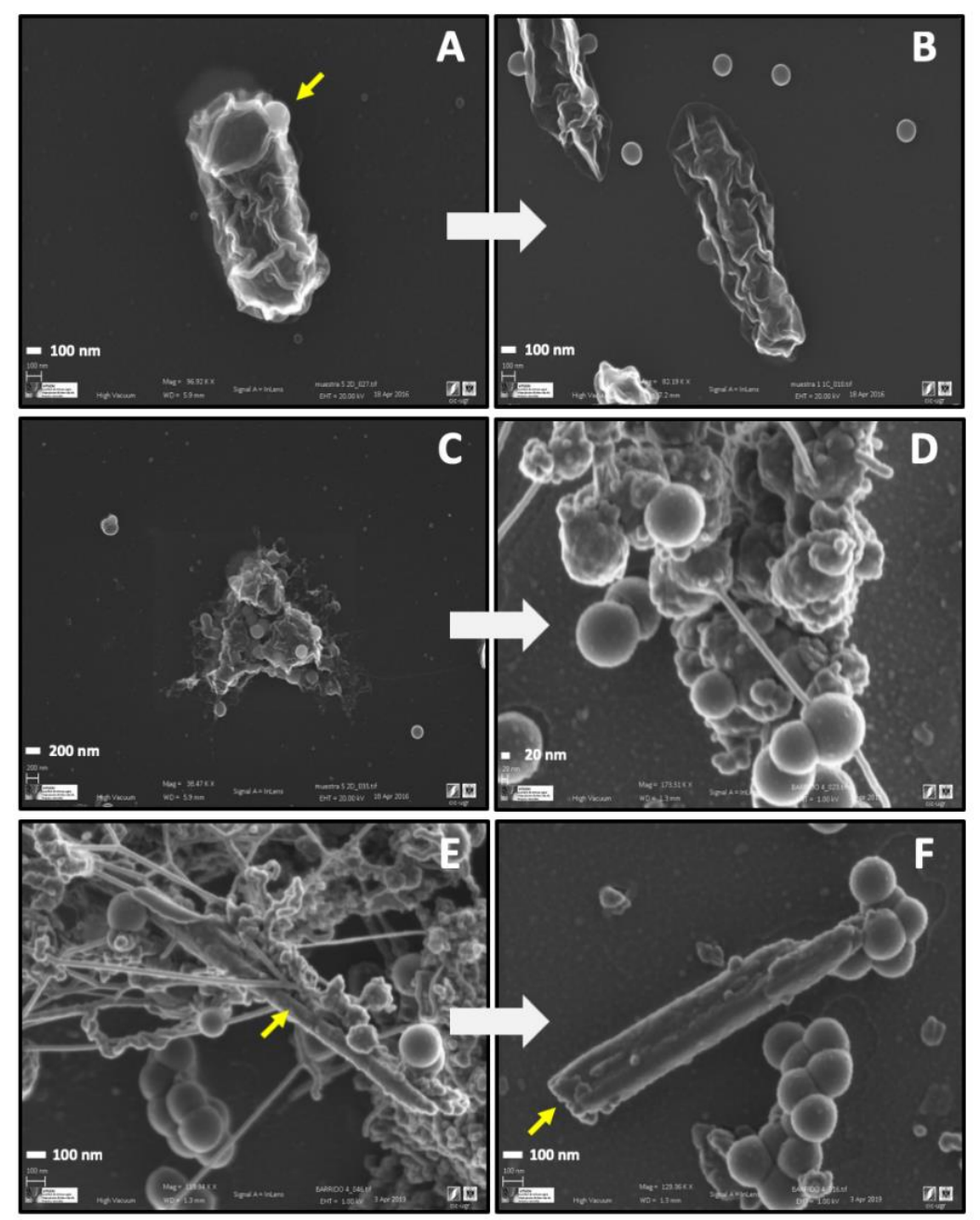

\section{Liberation of a-Se} nanospheres (smaller arrow) to the extracellular matrix probably through the bacterial cell lysis

\section{Aggregation of $\mathrm{Se}$ nanospheres probably using organic matter and flagella-like proteins as template and conversion to $\mathrm{m}$-Se}

\section{Formation of $t-S e$ nanowires (smaller arrows) probably originated from the nanospheres aggregates}

Figure 8. VP-FESEM images representing the proposed transformation from a-Se nanospheres to t-Se nanowires through the formation of $\mathrm{m}$-Se aggregates as an intermediate step by using proteins as a template. The images correspond to samples prepared by growing $S$. bentonitica anaerobically at an initial pH of 10. Scale bars: $100 \mathrm{~nm}(\mathbf{A}, \mathbf{B}, \mathbf{E}, \mathbf{F}), 200 \mathrm{~nm}(\mathbf{C})$, and $20 \mathrm{~nm}$ (D).

The small number of nanowires observed in comparison with our previous studies conducted under oxic conditions [17] points to the likelihood that under anaerobic and alkaline conditions, the cells need longer incubation times to produce Se crystals. A microscopic analysis of samples aerobically incubated supports this hypothesis, with a greater presence of Se crystals over time, from 15 to 30 days (Figure 9). This transformation is likely to occur more slowly because of the harsh conditions to which the cells were exposed. These conditions influenced the cell viability and proliferation, as revealed by flow cytometry, and would have also affected the processes of their reduction and transformation to Se crystals. 


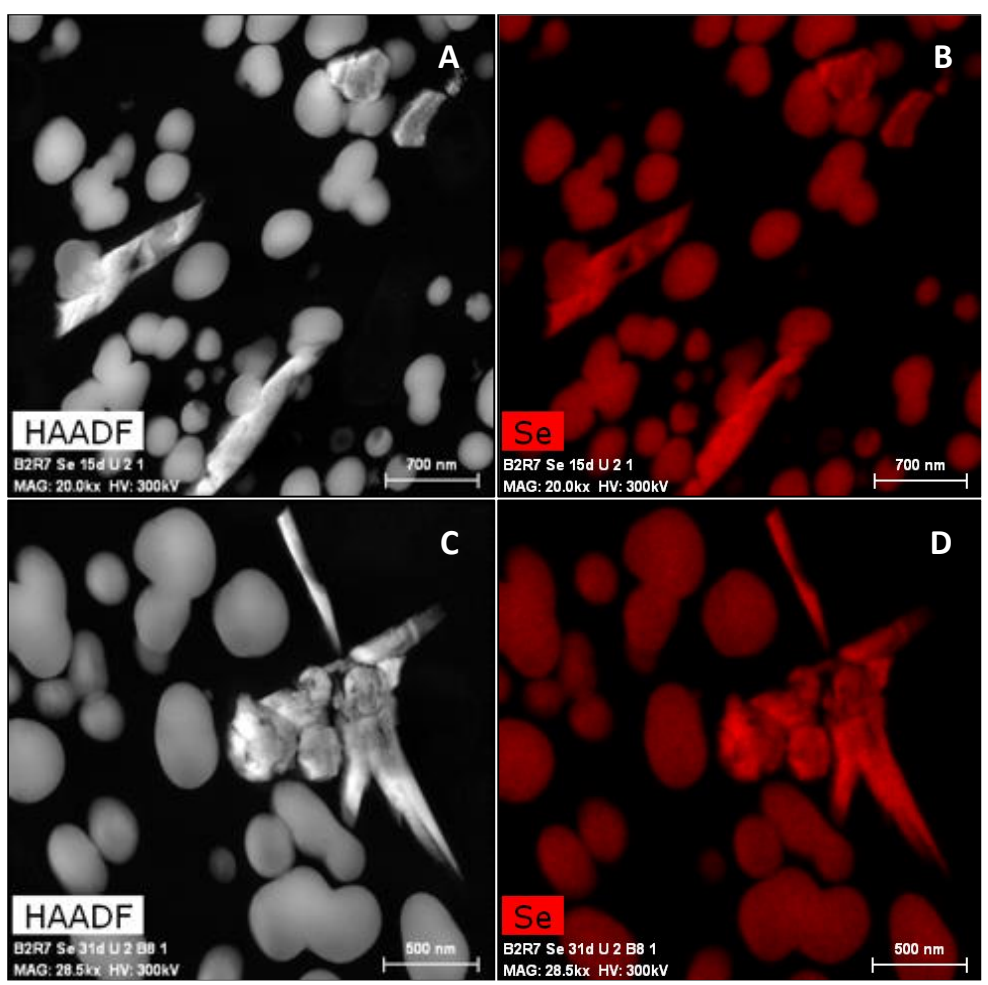

Figure 9. HAADF-STEM micrographs of Se nanostructures aerobically produced by S. bentonitica in the presence of $2 \mathrm{mM} \mathrm{Se}^{\mathrm{IV}}$ for 15 days (A-D). Corresponding elemental maps showing the Se composition of the nanostructures. Scale bars: $700 \mathrm{~nm}(\mathbf{A}, \mathbf{B})$ and $500 \mathrm{~nm}(\mathbf{C}, \mathbf{D})$.

The reduction from $\mathrm{Se}^{\mathrm{IV}}$ to $\mathrm{Se}^{0}$ under conditions simulating DGR (anaerobic and alkaline) would have a clearly positive impact onto the safety of these systems, due to the lower toxicity and mobility of Se at a zero valent oxidation state. However, the different Se structures and shapes produced must also be taken into account when predicting the specific influence of $S$. bentonitica cells. It is generally assumed that SeNPs are insoluble and non-toxic [40]. In fact, microbially produced Se nanospheres have been shown to be less toxic than oxidized Se species $\left(\mathrm{Se}^{\mathrm{VI}}\right.$ and $\left.\mathrm{Se}^{\mathrm{IV}}\right)$ [46]. Thus, the production of Se nanospheres by $S$. bentonitica would be beneficial within a geodisposal system. Notwithstanding, there are considerable uncertainties about the toxicity of SeNPs compared to their soluble oxidized forms, according to some studies [47,48]. Li et al. [48] described a greater toxicity of SeNPs in comparison with $\mathrm{Se}^{\mathrm{IV}}$ in the fish Oryzias latipes. Kumar et al. [47] reported that the toxicity of SeNPs depends on their concentration, in this case documenting toxic effects on the fish species Pangasius hypophthalmus. Further research is needed to arrive at conclusive evidence for the toxicity level of SeNPs produced by S. bentonitica. The formation of crystalline Se in the form of nanowires could have a positive impact on the repositories, as suggested by their lower mobility and higher settleability when compared to Se nanospheres and oxyanions [49,50]. The lesser volume of Se crystalline nanowires observed indicates a lower short-term efficiency of S. bentonitica in the immobilization of the $\mathrm{Se}^{\mathrm{IV}}$ present in the repositories when anaerobic and alkaline conditions dominate, as opposed to aerobic studies [17].

\section{Materials and Methods}

\subsection{Bacterial Strain and Growth Conditions}

The bacterial strain S. bentonitica employed in the present study was isolated from Spanish bentonites collected in Cabo Gata Nature Park (Almeria, Spain) [51]. The bacterial cells were grown aerobically in a solid and liquid Luria-Bertani (LB) broth medium (tryptone $10 \mathrm{~g} / \mathrm{L}$, yeast extract $5 \mathrm{~g} / \mathrm{L}$ 
and $\mathrm{NaCl} 10 \mathrm{~g} / \mathrm{L}, \mathrm{pH} 7.0 \pm 0.2)$ at $28^{\circ} \mathrm{C}$. The $S$. bentonitica cells were inoculated to an initial optical density (O.D.) of 0.2 (at $600 \mathrm{~nm}$ ) for all the experiments.

\subsection{Anaerobic Growth under Selenite Stress}

S. bentonitica were grown in a degassed $\mathrm{R}^{2} \mathrm{~A}^{*}$ (modified composition: peptone $0.5 \mathrm{~g} / \mathrm{L}$, glucose $0.5 \mathrm{~g} / \mathrm{L}, \mathrm{K}_{2} \mathrm{HPO}_{4} 0.3 \mathrm{~g} / \mathrm{L}$, and $\mathrm{MgSO}_{4} 0.05 \mathrm{~g} / \mathrm{L}$ ) medium, to which we added with different electron donors (sodium acetate, citrate, pyruvate, etc.) and acceptors (sodium nitrate, iron (III) hydroxide, ferric citrate, etc.) in order to determine their ability to grow anaerobically. Cells were harvested at the mid-exponential phase by centrifugation $(10000 \times \mathrm{g} ; 10 \mathrm{~min})$ from LB cultures and washed with $30 \mathrm{mM}$ PIPES buffer to remove the medium's ingredients. Afterwards, the cells were re-suspended in $\mathrm{R}^{2} \mathrm{~A}^{*}$ supplemented with the corresponding electron donor and acceptor. An R2A* medium is commonly used to isolate bacteria from oligotrophic environments, including those from radioactive waste repositories $[52,53]$. This culture medium is, therefore, appropriate to study the influence of microbial processes on the mobility of radionuclides in the context of a DGR system. The component peptone was employed as a nitrogen and undefined electron donor source needed for the growth and the Se reduction processes. Acetate was added in addition to peptone since $S$. bentonitica uses just a few carbon sources and electron donors (acetate, gluconate) [35]. Se $\mathrm{I}^{\mathrm{IV}}$ at different concentrations (0.1 to $1 \mathrm{mM}$ ) was added to the mixture from a $1 \mathrm{M}$ sodium selenite $\left(\mathrm{Na}_{2} \mathrm{SeO}_{3}\right)$ (Sigma-Aldrich, St. Louis, $\mathrm{MO}$, USA) stock solution. The solubility of $\mathrm{Se}^{\mathrm{IV}}$ in this medium (R2A*) is not affected by its components, as demonstrated in our previous work with a more complex medium (LB-Luria Bertani) [17].

Finally, the suspensions were degassed using $\mathrm{N}_{2}$ and incubated at $28^{\circ} \mathrm{C}$. Se $\mathrm{S}^{\mathrm{IV}}$-untreated cells and an $\mathrm{R}^{2} \mathrm{~A}^{*}$ medium containing $\mathrm{Se}^{\mathrm{IV}}$ were used as controls. All the measurements were performed in triplicate. Growth was determined by quantifying the total protein content in the bacterial cell extracts using a modification of the method described by Dhanjal and Cameotra [54]. A $1 \mathrm{~mL}$ aliquot of bacterial culture was taken at different time intervals to measure growth, based on the protein content, using the Bradford reagent (Bio-Rad ${ }^{\mathrm{TM}}$ ) [55]. Bovine serum albumin (BSA) was used as a standard.

\subsection{Reduction of $S e^{I V}$ under Anaerobic and Alkaline Conditions}

The $\mathrm{Se}^{\mathrm{IV}}$ reduction ability of $S$. bentonitica was also assayed anaerobically under alkaline conditions (from $\mathrm{pH} 8$ to 11) relevant for the DGR system. The samples were prepared as described in the section above (Section 3.2.), using sodium acetate and sodium nitrate as the electron donor and acceptor, respectively. The $\mathrm{pH}$ of the solutions was adjusted by the addition of acid $\left(\mathrm{HClO}_{4}\right)$ or base $(\mathrm{NaOH})$ using a pH-meter (CRISON ${ }^{\odot}$ micro $\mathrm{pH}$ 2002, Barcelona, Spain), and the samples were sterilized by filtration through $0.22 \mu \mathrm{m}$ nitrocellulose filters prior to degassing.

\subsection{Flow Cytometry}

The cell viability and the metabolic activity of $S$. bentonitica in the presence of $\mathrm{Se}^{\mathrm{IV}}$ under anoxic conditions were determined by means of the flow cytometry technique. For this purpose, the cultures were prepared as described in Section 3.2 in the presence of acetate and nitrate, with an initial concentration of $\mathrm{Se}^{\mathrm{IV}} 2 \mathrm{mM}$. All experiments were conducted in triplicate. After 12, 60, and $144 \mathrm{~h}$ of incubation, the cells were collected by centrifugation at $11000 \times g$ and $4{ }^{\circ} \mathrm{C}$ for $10 \mathrm{~min}$. The resultant pellet was washed four times in phosphate buffered saline (PBS) with pH 7 . The cells were then dissolved in PBS, adjusting their cellular density to approximately $10^{6}$ cells $/ \mathrm{mL}$. For the cell viability test, fluorescein diacetate (FDA) and propidium iodide (PI) were added to each sample to final concentrations of $20 \mu \mathrm{L} / \mathrm{mL}$ and $2 \mu \mathrm{L} / \mathrm{mL}$, respectively. To perform the metabolic activity test, 3,30-dihexyloxacarbocyanine iodide $\left(\mathrm{DiOC}_{6}\right)$ was used at a final concentration of $20 \mu \mathrm{L} / \mathrm{mL}$. Finally, the samples were analysed by Forward Scatter using a FACSCanto II ${ }^{\mathrm{TM}}$ cytometer (Becton Dickinson, San Jose, CA, USA). Se $\mathrm{IV}^{\mathrm{IV}}$-free cultures and dead cells were obtained by heating the biomass at $90{ }^{\circ} \mathrm{C}$ served as controls. 


\subsection{Electron Microscopy}

Variable pressure field emission scanning electron microscopes (VP-FESEMs) equipped with an X-ray detector Raman spectroscopy system (SCA-Structural and Chemical Analyser, Gloucestershire, UK) made possible an in situ 3-D structural and elemental characterization of the reduced Se produced by the cells. $\mathrm{Se}^{\mathrm{IV}}$-amended cultures $(2 \mathrm{mM})$ with the addition of sodium acetate and sodium nitrate, respectively as electron donor and acceptor, were prepared for VP-FESEM after $144 \mathrm{~h}$ of anaerobic growth at different $\mathrm{pHs}(7-10)$ as described by Ruiz-Fresneda et al. [17]. The samples were analysed under a VP-FESEM Zeiss SUPRA 40VP (Carl Zeiss, Oberkochen, Germany).

The Se reduction products were also analysed by means of a scanning transmission electron microscope (STEM) equipped with energy dispersive X-ray (EDX). EDX analysis was performed at $300 \mathrm{kV}$ using a spot size of $4 \AA$ and a live counting time of $50 \mathrm{~s}$. The structural characterization of Se nanostructures was based on SAED. The samples were prepared as described in Merroun et al. [56] and examined under a high-angle annular dark field scanning transmission electron microscope (HAADF-STEM) FEI TITAN G2 80-300 (FEI Europe, Eindhoven, Netherlands). The STEM specimen holders were cleaned by plasma prior to STEM analysis to minimize contamination.

\section{Conclusions}

The present study describes the ability of bentonite-isolated S. bentonitica to reduce $\mathrm{Se}^{\mathrm{IV}}$ to $\mathrm{Se}^{0}$ under anaerobic and alkaline conditions, simulating those expected in a DGR. Despite the low cell viability, low activity, and absence of growth of $S$. bentonitica in the presence of $\mathrm{Se}^{\mathrm{IV}}$, individual and aggregated Se nanospheres and lower amounts of Se nanowires were produced as a consequence of the bioreduction process. A combination of microscopic and spectroscopic techniques suggested the transformation from a-Se nanospheres to crystalline Se nanowires (t-Se) in a way similar to that reported aerobically by Ruiz-Fresneda et al. [17]. A slower transformation process appears to occur due to the non-proliferation and low viability and activity rates of $S$. bentonitica cells, most likely caused by harsh environmental conditions. However, further studies are needed to confirm the proposed transformation process.

The redox transformation from toxic $\mathrm{Se}^{\mathrm{IV}}$ to non-toxic $\mathrm{Se}^{0}$ and the formation of crystalline Se nanowires suggests $S$. bentonitica to be a potential bacterial species with a positive effect on the safety of the DGR system in the event of a radionuclide escape. However, the slower transformation process suggests the limited short-term efficiency of S. bentonitica in the formation of crystalline Se and, hence, in the immobilization of Se when anaerobic and alkaline conditions predominate. More specific studies are needed to determine the mobility of the Se nanospheres produced by this bacterium within a DGR system. Still, the present study contributes to our understanding of the impact of microbial processes on the toxicity of Se in the future disposal of radioactive waste.

Author Contributions: Conceptualization, M.L.M.; methodology, M.A.R.-F., J.G.-B., M.d.M.A.-O., I.G.-T., and J.D.-M.; software, M.A.R.-F., M.d.M.A.-O., and I.G.-T.; validation, M.L.M; formal analysis, M.A.R.-F.; investigation, M.A.R.-F. and M.L.M.; resources, M.A.R.-F. and M.L.M.; data curation, M.A.R.-F. and M.L.M.; writing—original draft preparation, M.A.R.-F.; writing—review and editing, M.A.R.-F. and M.L.M.; visualization, M.A.R.-F.; supervision, M.L.M.; project administration, M.L.M.; funding acquisition, M.L.M.

Funding: This work was supported by the Euratom research and training programme 2014-2018 under grant agreement no. 661880 .

Acknowledgments: This work was supported by the Euratom research and training programme 2014-2018 [grant agreement no. 661880]. The authors acknowledge the assistance of Concepción Hernández Castillo (Centro de Instrumentación Científica, University of Granada, Spain) for their help with sample preparation for microscopy. The authors also thank the assistance of Jaime Lazuen Alcón (Centro de Instrumentación Científica, University of Granada, Spain) with the flow cytometry measurements.

Conflicts of Interest: The authors declare no conflict of interest. 


\section{References}

1. International Atomic Energy Agency (IAEA). Scientific and Technical Basis for the Geological Disposal of Radioactive Wastes. TR-413, STI/DOC/010/413. Vienna, IAEA 2003. Available online: https://www-pub.iaea. org/MTCD/Publications/PDF/TRS413_web.pdf (accessed on 23 October 2019).

2. Delage, P.; Cui, Y.; Tang, A. Clays in radioactive waste disposal. J. Rock Mech. Geotech. Eng. 2010, 2, 111-123. [CrossRef]

3. Alonso, J.; Becker, D.A.; Storck, R.; Besnus, F.; Pellegrini, D.; Serres, C.; Johnson, L.; Hart, J.; Marivoet, J.; Vieno, T.; et al. Bentonite barriers in integrated performance assessment (Benipa). European Commission, Nuclear Science and Technology, Report EUR 21023 EN. 2004. Available online: http://elibrary.cenn.org/Report/ Bentonite\%20Barries\%20in\%20Integrated\%20Performance\%20Assessment\%20Benipa/Part_2.pdf (accessed on 23 October 2019).

4. Berner, U. Evolution of pore water chemistry during degradation of cement in a radioactive waste repository environment. Waste Manag. 1992, 12, 201-219. [CrossRef]

5. Pedersen, K.; Nilsson, E.; Arlinger, J.; Hallbeck, L.; O'Neill, A. Distribution, diversity and activity of microorganisms in the hyper-alkaline spring waters of Maqarin in Jordan. Extremophiles 2004, 8, 151-164. [CrossRef] [PubMed]

6. Maugeri, T.L.; Lentini, V.; Gugliandolo, C.; Italiano, F.; Cousin, S.; Stackebrandt, E. Bacterial and archaeal populations at two shallow hydrothermal vents off Panarea Island (Eolian Islands, Italy). Extremophiles 2009, 13, 199-212. [CrossRef]

7. Lloyd, J.R. Microbial reduction of metals and radionuclides. FEMS Microbiol. Rev. 2003, 27, 411-425. [CrossRef]

8. Borghese, R.; Baccolini, C.; Francia, F.; Sabatino, P.; Turner, R.J.; Zannoni, D. Reduction of chalcogen oxyanions and generation of nanoprecipitates by the photosynthetic bacterium Rhodobacter capsulatus. J. Hazard. Mater. 2014, 269, 24-30. [CrossRef]

9. Dardenne, K.; González-Robles, E.; Rothe, J.; Müller, N.; Christill, G.; Lemmer, D.; Praetorius, R.; Kienzler, B.; Metz, V.; Roth, G.; et al. XAS and XRF investigation of an actual HAWC glass fragment obtained from the Karlsruhe vitrification plant (VEK). J. Nucl. Mater. 2015, 460, 209-215. [CrossRef]

10. Antonioli, P.; Lampis, S.; Chesini, I.; Vallini, G.; Rinalducci, S.; Zolla, L.; Righetti, P.G. Stenotrophomonas maltophilia SeITE02, a new bacterial strain suitable for bioremediation of selenite-contaminated environmental matrices. Appl. Environ. Microbiol. 2007, 73, 6854-6863. [CrossRef]

11. Lampis, S.; Zonaro, E.; Bertolini, C.; Cecconi, D.; Monti, F.; Micaroni, M.; Turner, R.J.; Butler, C.S.; Vallini, G. Selenite biotransformation and detoxification by Stenotrophomonas maltophilia SeITE02: Novel clues on the route to bacterial biogenesis of selenium nanoparticles. J. Hazard. Mater. 2017, 324, 3-14. [CrossRef]

12. Tan, Y.; Wang, Y.; Wang, Y.; Xu, D.; Huang, Y.; Wang, D.; Wang, G.; Rensing, C.; Zheng, S. Novel mechanisms of selenate and selenite reduction in the obligate aerobic bacterium Comamonas testosteroni S44. J. Hazard. Mater. 2018, 359, 129-138. [CrossRef]

13. Kora, A.J. Bacillus cereus, selenite-reducing bacterium from contaminated lake of an industrial area: A renewable nanofactory for the synthesis of selenium nanoparticles. Bioresour. Bioprocess. 2018, 5, 30. [CrossRef]

14. Fernández-Llamosas, H.; Castro, L.; Blázquez, M.L.; Díaz, E.; Carmona, M. Biosynthesis of selenium nanoparticles by Azoarcus sp. CIB. Microb. Cell Factories 2016, 15, 109. [CrossRef] [PubMed]

15. Dungan, R.S.; Yates, S.R.; Frankenberger, W.T. Transformations of selenate and selenite by Stenotrophomonas maltophilia isolated from a seleniferous agricultural drainage pond sediment. Environ. Microbiol. 2003, 5, 287-295. [CrossRef] [PubMed]

16. Li, D.-B.; Cheng, Y.-Y.; Wu, C.; Li, W.-W.; Li, N.; Yang, Z.-C.; Tong, Z.-H.; Yu, H.-Q. Selenite reduction by Shewanella oneidensis MR-1 is mediated by fumarate reductase in periplasm. Sci. Rep. 2014, 4, 1-7. [CrossRef] [PubMed]

17. Fresneda, M.A.R.; Martín, J.D.; Bolívar, J.G.; Cantos, M.V.F.; Bosch-Estévez, G.; Moreno, M.F.M.; Merroun, M.L. Green synthesis and biotransformation of amorphous Se nanospheres to trigonal 1D Se nanostructures: Impact on Se mobility within the concept of radioactive waste disposal. Environ. Sci. Nano 2018, 5, 2103-2116. [CrossRef]

18. Williamson, A.J.; Morris, K.; Law, G.T.W.; Rizoulis, A.; Charnock, J.M.; Lloyd, J.R. Microbial Reduction of $\mathrm{U}(\mathrm{VI})$ under alkaline conditions: implications for radioactive waste geodisposal. Environ. Sci. Technol. 2014, 48, 13549-13556. [CrossRef] 
19. Smith, S.L.; Boothman, C.; Williams, H.A.; Ellis, B.L.; Wragg, J.; West, J.M.; Lloyd, J.R. Microbial impacts on $99 \mathrm{mTc}$ migration through sandstone under highly alkaline conditions relevant to radioactive waste disposal. Sci. Total. Environ. 2017, 575, 485-495. [CrossRef]

20. Villar, M.V.; Pérez del Villar, L.; Martín, P.L.; Pelayo, M.; Fernández, A.M.; Garralon, A.; Cuevas, J.; Leguey, S.; Caballero, E.; Huertas, F.; et al. The study of Spanish clays for their use as sealing materials in nuclear waste repositories: 20 years of progress. J. Iber. Geol. 2006, 32, 15-36.

21. Pearce, C.I.; Coker, V.S.; Charnock, J.M.; Pattrick, R.A.D.; Mosselmans, J.F.W.; Law, N.; Beveridge, T.J.; Lloyd, J.R. Microbial manufacture of chalcogenide-based nanoparticles via the reduction of selenite usingVeillonella atypica: Anin situEXAFS study. Nanotechnol. 2008, 19, 155603. [CrossRef]

22. Kessi, J.; Hanselmann, K.W. Similarities between the abiotic reduction of selenite with glutathione and the dissimilatory reaction mediated by rhodospirillum rubrum and escherichia coli. J. Boil. Chem. 2004, 279, 50662-50669. [CrossRef]

23. Pearce, C.I.; Pattrick, R.A.; Law, N.; Charnock, J.M.; Coker, V.S.; Fellowes, J.W.; Oremland, R.S.; Lloyd, J.R. Investigating different mechanisms for biogenic selenite transformations: Geobacter sulfurreducens, Shewanella oneidensisandVeillonella atypica. Environ. Technol. 2009, 30, 1313-1326. [CrossRef] [PubMed]

24. Tam, K.; Ho, C.T.; Lee, J.-H.; Lai, M.; Chang, C.H.; Rheem, Y.; Chen, W.; Hur, H.-G.; Myung, N.V. Growth mechanism of amorphous selenium nanoparticles synthesized by Shewanella sp. HN-41. Biosci. Biotechnol. Biochem. 2010, 74, 696-700. [CrossRef] [PubMed]

25. Klonowska, A.; Heulin, T.; Vermeglio, A. Selenite and tellurite reduction by shewanella oneidensis. Appl. Environ. Microbiol. 2005, 71, 5607-5609. [CrossRef] [PubMed]

26. Nancharaiah, Y.V.; Lens, P.N.L. Ecology and biotechnology of selenium-respiring bacteria. Microbiol. Mol. Boil. Rev. 2015, 79, 61-80. [CrossRef]

27. Basaglia, M.; Toffanin, A.; Baldan, E.; Bottegal, M.; Shapleigh, J.P.; Casella, S. Selenite-reducing capacity of the copper-containing nitrite reductase of Rhizobium sullae. FEMS Microbiol. Lett. 2007, 269, 124-130. [CrossRef]

28. DeMoll-decker, H.; Macy, J.M. The periplasmic nitrite reductase of Thauera selenatis may catalyze the reduction of selenite to elemental selenium. Arch. Microbiol. 1993, 160, 241-247.

29. Abrahamsen, L.; Arnold, T.; Brinkmann, H.; Leys, N.; Merroun, M.; Mijnendonckx, K.; Moll, H.; Polvika, P.; Sevcu, J.; Small, J.; et al. A review of anthropogenic organic wastes and their degradation behaviour. Microbiology In Nuclear waste Disposal (MIND project) 2015, 97. Available online: https://igdtp.eu/wpcontent/uploads/2017/10/MIND-2015-12-D1.1-ReviewOfAnthropogenicOrganicWastes.pdf (accessed on 23 October 2019).

30. Bertron, A.; Jacquemet, N.; Erable, B.; Sablayrolles, C.; Escadeillas, G.; Albrecht, A. Reactivity of nitrate and organic acids at the concrete-bitumen interface of a nuclear waste repository cell. Nucl. Eng. Des. 2014, 268, 51-57. [CrossRef]

31. Walczak, I.; Camaro, S.; Blanchard, J.-M. Quantitative and qualitative analysis of hydrosoluble organic matter in bitumen leachates. Agron. EDP Sci. 2001, 21, 247-257. [CrossRef]

32. Givan, A.L. Flow Cytometry: An Introduction. In Flow Cytometry Protocols; Hawley, T.S., Hawley, R.G., Eds.; Humana Press: New York, NY, USA, 2011; pp. 1-29. [CrossRef]

33. Stubberfield, L.; Shaw, P. A comparison of tetrazolium reduction and FDA hydrolysis with other measures of microbial activity. J. Microbiol. Methods 1990, 12, 151-162. [CrossRef]

34. David, F.; Berger, A.; Hänsch, R.; Rohde, M.; Franco-Lara, E. Single cell analysis applied to antibody fragment production with Bacillus megaterium: Development of advanced physiology and bioprocess state estimation tools. Microb. Cell Factories 2011, 10, 23. [CrossRef]

35. Sánchez-Castro, I.; Ruiz-Fresneda, M.A.; Bakkali, M.; Kämpfer, P.; Glaeser, S.P.; Busse, H.J.; López-Fernández, M.; Martínez-Rodríguez, P.; Merroun, M.L. Stenotrophomonas bentonitica sp. nov., isolated from bentonite formations. Int. J. Syst. Evol. Microbiol. 2017, 67, 2779-2786. [CrossRef] [PubMed]

36. Rizoulis, A.; Steele, H.M.; Morris, K.; Lloyd, J.R.; Lloyd, J. The potential impact of anaerobic microbial metabolism during the geological disposal of intermediate-level waste. Miner. Mag. 2012, 76, 3261-3270. [CrossRef]

37. Wang, T.; Yang, L.; Zhang, B.; Liu, J. Extracellular biosynthesis and transformation of selenium nanoparticles and application in $\mathrm{H}_{2} \mathrm{O}_{2}$ biosensor. Colloids Surf. B: Biointerfaces 2010, 80, 94-102. [CrossRef] [PubMed]

38. Kora, A.J.; Rastogi, L. Bacteriogenic synthesis of selenium nanoparticles by Escherichia coli ATCC 35218 and its structural characterisation. IET Nanobiotechnol. 2016, 11, 179-184. [CrossRef] 
39. Zhang, W.; Chen, Z.; Liu, H.; Zhang, L.; Gao, P.; Li, D. Biosynthesis and structural characteristics of selenium nanoparticles by Pseudomonas alcaliphila. Colloids Surf. B: Biointerfaces 2011, 88, 196-201. [CrossRef]

40. Husen, A.; Siddiqi, K. Plants and microbes assisted selenium nanoparticles: Characterization and application. J. Nanobiotechnol. 2014, 12, 28. [CrossRef]

41. Jóvári, P.; Delaplane, R.G.; Pusztai, L. Structural models of amorphous selenium. Phys. Rev. B 2003, 67, 172201. [CrossRef]

42. Fernández-Martínez, A.; Charlet, L. Selenium environmental cycling and bioavailability: A structural chemist point of view. Rev. Environ. Sci. Bio/Technol. 2009, 8, 81-110. [CrossRef]

43. Cooper, W.C.; Westbury, A. The structure of selenium. In Selenium; Zingaro, R.A., Cooper, W.C., Eds.; Van Nostrand Reinhold Company: New York, NY, USA, 1974; Chapter 3; pp. 148-173.

44. Popov, A. Correlation between the molecular structure and properties of amorphous selenium. J. Phys. C Solid State Phys. 1976, 9, 675. [CrossRef]

45. Chen, H.; Shin, D.-W.; Nam, J.-G.; Kwon, K.-W.; Yoo, J.-B. Selenium nanowires and nanotubes synthesized via a facile template-free solution method. Mater. Res. Bull. 2010, 45, 699-704. [CrossRef]

46. Benkő, I.; Nagy, G.; Tanczos, B.; Ungvari, E.; Sztrik, A.; Eszenyi, P.; Prokisch, J.; Banfalvi, G. Subacute toxicity of nano-selenium compared to other selenium species in mice. Environ. Toxicol. Chem. 2012, 31, 2812-2820. [CrossRef] [PubMed]

47. Kumar, N.; Krishnani, K.K.; Singh, N.P. Comparative study of selenium and selenium nanoparticles with reference to acute toxicity, biochemical attributes, and histopathological response in fish. Environ. Sci. Pollut. Res. 2018, 25, 8914-8927. [CrossRef] [PubMed]

48. Li, H.; Zhang, J.; Wang, T.; Luo, W.; Zhou, Q.; Jiang, G. Elemental selenium particles at nano-size (Nano-Se) are more toxic to Medaka (Oryzias latipes) as a consequence of hyper-accumulation of selenium: A comparison with sodium selenite. Aquat. Toxicol. 2008, 89, 251-256. [CrossRef] [PubMed]

49. Jain, R.; Jordan, N.; Tsushima, S.; Hübner, R.; Weiss, S.; Lens, P.N.L. Shape change of biogenic elemental selenium nanomaterials from nanospheres to nanorods decreases their colloidal stability. Environ. Sci. Nano 2017, 4, 1054-1063. [CrossRef]

50. Lenz, M.; Van Aelst, A.; Smit, M.; Corvini, P.; Lens, P.N. Biological Production of Selenium Nanoparticles from Waste Waters. Adv. Mater. Res. 2009, 71,721-724. [CrossRef]

51. López-Fernández, M.; Fernandez-Sanfrancisco, O.; Moreno-García, A.; Martín-Sánchez, I.; Sánchez-Castro, I.; Merroun, M.L. Microbial communities in bentonite formations and their interactions with uranium. Appl. Geochem. 2014, 49, 77-86. [CrossRef]

52. Nedelkova, M.; Merroun, M.L.; Merroun, M.L.; Rossberg, A.; Hennig, C.; Selenska-Pobell, S. Microbacterium isolates from the vicinity of a radioactive waste depository and their interactionswith uranium. FEMS Microbiol. Ecol. 2007, 59, 694-705. [CrossRef]

53. Kumar, R.; Nongkhlaw, M.; Acharya, C.; Joshi, S.R. Uranium (U)-tolerant bacterial diversity from U ore deposit of Domiasiat in North-East India and its prospective utilisation in bioremediation. Microbes Environ. 2013, 28, 33-41. [CrossRef]

54. Dhanjal, S.; Cameotra, S.S. Aerobic biogenesis of selenium nanospheres by Bacillus cereus isolated from coalmine soil. Microb. Cell Factories 2010, 9, 52. [CrossRef]

55. Bradford, M.M. A rapid and sensitive method for the quantitation of microgram quantities of protein utilizing the principle of protein-dye binding. Anal. Biochem. 1976, 72, 248-254. [CrossRef]

56. Merroun, M.L.; Raff, J.; Rossberg, A.; Hennig, C.; Reich, T.; Selenska-Pobell, S. Complexation of Uranium by Cells and S-Layer Sheets of Bacillus sphaericus JG-A12. Appl. Environ. Microbiol. 2005, 71, 5532-5543. [CrossRef] [PubMed]

Sample Availability: Samples of the compounds are available from the authors. 